\author{
KRZYSZTOF NOWICKI \\ ORCID: 0000-0002-3692-2563 \\ Uniwersytet Wrocławski
}

\title{
CZY PRZEWIDYWANE ZMIANY W POLSKIM PROCESIE KARNYM MUSZĄ WIĄZAĆ SIĘ Z ISTOTNYM OGRANICZENIEM ZASADY BEZPOŚREDNIOŚCI?
}

\begin{abstract}
Abstrakt: Zasada bezpośredniości pełni bardzo istotną rolę w procesie karnym. Reguły tworzące tę zasadę mają bezpośrednie przełożenie na realizację zasady prawdy materialnej, wskazują bowiem jakiego typu dowody powinny podlegać ocenie sądu, aby dokonywał ustaleń zgodnych z rzeczywistością. Niniejsze opracowanie przedstawi rolę i zakres zasady bezpośredniości. Analizie poddane zostaną przeprowadzone w ostatnich latach zmiany przepisów mającee wpływ na funkcjonowanie tej zasady oraz ocena tych regulacji. Opracowanie ma też przybliżyć ewentualne zagrożenia dla należytego funkcjonowania polskiego procesu karnego związane z dalszym rozszerzeniem zasady bezpośredniości.
\end{abstract}

Słowa kluczowe: proces karny, zasada bezpośredniości, model racjonalnego tworzenia prawa, gwarancje procesowe

\section{UWAGI WSTĘPNE}

W ostatnich latach przeprowadzono wiele nowelizacji przepisów regulujących polski proces karny. Pamiętać jednak należy, że omawiane nowele w dużej mierze odnosiły się do postępowania dowodowego, zaś zasada bezpośredniości jest jedną z najważniejszych zasad tegoż postępowania wskazującą na metodę przeprowadzania dowodów w sprawie. Ma ona wpływ na ukształtowanie polskiego procesu karnego. Potrzeba funkcjonowania zasady bezpośredniości w nowoczesnym postępowaniu karnym nie powinna budzić kontrowersji. Niemniej wszechstronna analiza przepisów kształtujących tę zasadę pozwoli na ocenę jej rangi w polskim procesie karnym oraz gwarancji, jakie wiążą się z jej realizacją. Jednocześnie należy rozważyć możliwość ewentualnych zmian rozszerzających lub ograniczających wyjątki od zasady bezpośredniości. 


\section{ISTOTA ZASADY BEZPOŚREDNIOŚCI}

Zasada bezpośredniości była wyróżniana w literaturze polskiego procesu karnego już na początku XX wieku, po odzyskaniu niepodległości ${ }^{1}$. Opisując tę zasadę, wskazywano na jej związek z postępowaniem dowodowym oraz istotną rolę w ujawnieniu i ustaleniu okoliczności mających znaczenie dla rozstrzygnięcia sprawy $^{2}$. Rozumienie tej zasady w późniejszym okresie ulegało nieznacznej modyfikacji ${ }^{3}$, niemniej rozróżnienie i opis jej najważniejszych elementów nie uległy istotnym zmianom do dnia dzisiejszego.

W literaturze brak jednolitych poglądów odnośnie do zakresu przedmiotowego zasady bezpośredniości. Wiąże się to między innymi z tym, że zasada bezpośredniości jest niezdefiniowana prawnie, zaś określenie kształtujących ją elementów wymaga analizy wielu przepisów karnoprocesowych. Opisując zasadę bezpośredniości, S. Waltoś formułuje dwie dyrektywy. Zgodnie z pierwszą organ procesowy powinien zetknąć się osobiście ze źródłem i środkiem dowodowym. Natomiast druga dyrektywa nakazuje organowi dokonywać ustaleń w procesie przede wszystkim za pomocą dowodów pierwotnych i w miarę możliwości nie zastępować ich przez dowody pochodne ${ }^{4}$.

Część przedstawicieli doktryny wskazuje natomiast na to, że zasada bezpośredniości obejmuje trzy dyrektywy i kieruje je do sądu. Odwołują się one do postulatów, aby sąd opierał się wyłącznie na dowodach przeprowadzonych podczas rozprawy, miał bezpośredni kontakt ze źródłami i środkami dowodowymi, a także, aby opierał się przede wszystkim na dowodach pierwotnych ${ }^{5}$. W literaturze wskazuje się także, że spełnienie dyrektywy bezpośredniości wymaga zredukowania do minimum ogniw dowodowych pomiędzy poznawanymi okolicznościami istotnymi dla rozstrzygnięcia sprawy, a składem orzekającym ${ }^{6}$.

1 S. Glaser, Wstep do nauki procesu karnego, Warszawa 1928, s. 88-91; idem, Zarys polskiego procesu karnego, Warszawa 1929, s. 181.

2 S. Glaser, op. cit., s. 88.

3 Por. na przykład S. Śliwiński, Polski proces karny przed sądem powszechnym. Zasady ogólne, Warszawa 1948, s. 126; M. Cieślak, Zagadnienia dowodowe w procesie karnym, t. 1, Warszawa 1955 , s. $185 \mathrm{n}$.

${ }^{4}$ S. Waltoś, Proces karny, Zarys systemu, Warszawa 2009, s. 268-269. Zob też H. Paluszkiewicz, Pierwszoinstancyjne wyrokowanie merytoryczne poza rozprawa w polskim procesie karnym, Warszawa 2008, s. 240.

5 Por. na przykład M. Cieślak, op. cit., s. 186; T. Nowak, Zasada bezpośredniości w polskim procesie karnym, Poznań 1971, s. 44 n.; W. Daszkiewicz, Prawo karne procesowe. Zagadnienia ogólne, t. 1, Bydgoszcz 1999, s. 107; J. Tylman, [w:] Polskie postępowanie karne, red. T. Grzegorczyk, J. Tylman, Warszawa 2001, s. 94; R. Kmiecik, [w:] Prawo dowodowe. Zarys wykładu, red. R. Kmiecik, Kraków 2005 s. 93; J. Grajewski, [w:] Prawo karne procesowe - część ogólna, red. J. Grajewski, Warszawa 2011, s. 104.

${ }^{6}$ Por. na przykład M. Cieślak, op. cit., s. 185; T. Nowak, op. cit., s. 44 n.; J. Tylman, op. cit., s. 94. 


\section{WAŻNA ROLA ZASADY BEZPOŚREDNIOŚCI W PROCESIE KARNYM}

2.1. Reguły tworzące tę zasadę mają bezpośrednie przełożenie na realizację zasady prawdy materialnej, wskazują bowiem, jakiego typu dowody powinny podlegać ocenie sądu, aby mógł on dokonywać ustaleń zgodnych z rzeczywistością 7 . $\mathrm{Z}$ założenia poznawanie przez sąd faktów związanych z prowadzonym procesem będzie zawsze miało charakter pośredni, sędziowie nigdy bowiem nie mogą być świadkami czynu, który mają sądzić (art. $40 \S 1$ pkt 4 k.p.k.). Natomiast dbałość o dokonanie prawdziwych ustaleń faktycznych powinna wiązać się z ograniczeniem ogniw dowodowych pomiędzy ocenianymi okolicznościami a sądem. Jak słusznie wskazuje J. Tylman, z doświadczenia życiowego i zasad logicznego rozumowania wynika, że im więcej takich pośrednich ogniw, tym większe ryzyko zniekształceń przy rozpoznawaniu sprawy ${ }^{8}$.

Bezpośredni kontakt $\mathrm{z}$ osobą przesłuchiwaną pozwala również na szersze wykorzystanie reguł dotyczących oceny wiarygodności źródeł dowodowych. Taki sposób przeprowadzania dowodu daje sądowi przy przesłuchaniu świadka lub oskarżonego możliwość zapoznania się z ich relacją bez jakichkolwiek pośredników. Bezpośrednie przesłuchanie umożliwia wykorzystanie obserwacji zachowania osoby przesłuchiwanej i wyciąganie odpowiednich wniosków w tym zakresie. Jako przykład zachowania mogącego mieć wpływ na ocenę wiarygodności relacji świadka lub oskarżonego można wskazać: sposób wypowiedzi pozwalający ocenić spontaniczność relacji, gestykulację i mimikę osoby przesłuchiwanej, czas oraz sposób reakcji na zadawane pytania, a także czas, jakiego potrzebuje zapytana osoba na rozpoczęcie odpowiedzi po usłyszeniu pytania.

2.2. Bezpośrednie przeprowadzenie dowodu ma nie tylko duże znaczenie dla sądu, ale też dla stron. Mogą one na równi z sądem zetknąć się ze źródłami i środkami dowodowymi. Pozwala to stronom na realizację swoich gwarancji procesowych oraz ochronę własnych praw ${ }^{9}$. Mają one możliwość kontroli czynności przeprowadzanej przez sąd czy zgodności jej utrwalenia z rzeczywistym przebiegiem.

2.3. Bezpośredniość przeprowadzanych czynności dowodowych daje też możliwość realizacji uprawnień związanych z kontradyktoryjnym sporem procesowym. Strony mają bowiem możliwość obserwacji przesłuchiwanej osoby i ocenę jej wiarygodności, reagowania na jej relację, zadawania pytań czy składania wniosków dowodowych bez zbędnej zwłoki. W takiej sytuacji strony mogą ponadto lepiej kontrolować działania dowodowe sądu. Część z tych uprawnień nie może być realizowana na przykład w sytuacji odczytywania przez sąd zeznań złożonych

${ }^{7}$ Por. na przykład A. Murzynowski, Istota i zasady procesu karnego, Warszawa 1994, s. 315; K. Marszał, Proces karny, Katowice 1997, s. 64; J. Tylman, op. cit., s. 94; A. Gaberle, Dowody w sadowym procesie karnym, Kraków 2007, s. 77.

8 Zob. J. Tylman, op. cit., s. 94 oraz literaturę tam wskazaną.

9 Ibidem. 
w postępowaniu przygotowawczym. Z tego względu w literaturze mówi się także o bezpośredniości wobec stron ${ }^{10}$.

2.4. Bezpośredniość służy realizacji jawności zewnętrznej (obecność publiczności), dając opinii publicznej możliwość przynajmniej potencjalnej kontroli realizacji wymiaru sprawiedliwości w sprawach karnych (dotyczy to na przykład możliwości odczytania dowodu).

\section{ODSTĘPSTWA OD ZASADY BEZPOŚREDNIOŚCI}

Zgodnie z wcześniejszymi uwagami brak przepisów wprost regulujących zasadę bezpośredniości. Niemniej istnieją regulacje, na bazie których można ustalić kształtujące ją dyrektywy. W literaturze jako przepisy mające szczególnie istotne znaczenie dla funkcjonowania omawianej zasady wskazuje się art. 92 k.p.k. przyjmujący, że podstawę orzeczenia może stanowić tylko całokształt okoliczności ujawnionych w postępowaniu mających znaczenie dla rozstrzygnięcia sprawy, oraz art. 410 k.p.k., zgodnie z którym podstawę wyroku może stanowić tylko całokształt okoliczności ujawnionych w toku rozprawy głównej ${ }^{11}$. Podaje się, że przeprowadzanie dowodów „siłą rzeczy oznacza kontakt z nimi sądu i to kontakt zazwyczaj bezpośredni"12.

Inni autorzy podstawę normatywną zasady bezpośredniości widzą w tych przepisach Kodeksu postępowania karnego, które przewidują bezpośrednie przeprowadzenie dowodu jako regułę, natomiast pośrednie sposoby przeprowadzania dowodów są traktowane jako wyjątkowe ${ }^{13}$. Na uzasadnienie takiego stanowiska wskazuje się przede wszystkim treść regulacji art. 174 i art. 395 k.p.k. oraz a contrario art. 389 i 391-393a k.p.k. ${ }^{14}$ Przepis art. 174 k.p.k. stanowi, że dowodu z wyjaśnień oskarżonego lub z zeznań świadka nie wolno zastępować treścią pism, zapisków lub notatek urzędowych. Jak słusznie wskazują T. Grzegorczyk i J. Tylman, zakaz skonstruowany w tej regulacji ma jednak zasięg ograniczony z punktu widzenia dyrektyw omawianej zasady i nie dotyczy między innymi zakazu zastępowania oryginału dokumentu jego kopią lub świadka naocznego — świadkiem ze słuchu ${ }^{15}$. Możliwość takich działań będzie poddana analizie przy okazji omawiania innych przepisów w dalszej części opracowania. Natomiast art. 395

10 M. Cieślak, op. cit., s. 192.

11 Por. na przykład S. Waltoś, op. cit., s. 269-270.

12 J. Tylman, op. cit., s. 96.

13 Por. na przykład R. Kmiecik, op. cit., s. 95; J. Tylman, op. cit., s. 95-96; J. Skorupka, [w:] Proces karny, red. J. Skorupka, Warszawa 2020, s. 191-192.

14 Por. obszerne uwagi H. Paluszkiewicz, Zasada bezpośredniości, [w:] System prawa karnego procesowego, red. P. Hofmański, t. 3. Zasady procesu karnego, cz. 2, red. P. Wiliński, Warszawa 2014, s. 1058-1060 oraz literaturę i orzecznictwo tam wskazane.

15 J. Tylman, op. cit., s. 97. 
k.p.k. nakazuje przy braku przeszkód związanych z właściwościami dowodów rzeczowych sprowadzać je na salę rozpraw i udostępnić stronom, a w razie potrzeby - świadkom i biegłym. Sąd ma więc co do zasady za zadanie przeprowadzać taki dowód bezpośrednio na rozprawie. Dopiero w sytuacji, gdy zapoznanie się z dowodem rzeczowym lub przeprowadzenie oględzin przez pełny skład sądu napotyka znaczne trudności albo jeżeli strony wyrażają na to zgodę, sąd może wyznaczyć do tej czynności sędziego ze swego składu albo sąd wezwany (art. 396 $\S 1$ k.p.k.).

Przepisy kodeksu postępowania karnego przewidują szereg możliwych odstępstw od reguł związanych z zasadą bezpośredniości. Można je usystematyzować w kilku poniżej przedstawionych kategoriach.

1) Ustalenie faktu za pomocą dowodu pochodnego, jeżeli dowód pierwotny nie jest dostępny lub nie istnieje ${ }^{16}$. W pierwszym przypadku brak dowodu ma charakter względny, co oznacza, że taki dowód istnieje, ale brakuje możliwości jego przeprowadzenia, na przykład świadek na stałe przebywa za granicą. Druga sytuacja oznacza bezwzględny brak dowodu, gdy na przykład doszło do zniszczenia oryginału dokumentu lub poważnego jego uszkodzenia. Do tej kategorii należy zaliczyć też przykładowo śmierć świadka lub jego brak pamięci odnośnie do faktów istotnych dla rozstrzygnięcia sprawy.

2) Zachodzi potrzeba sprawdzenia lub uzupełnienia dowodu. Dotychczas najczęściej związane jest to z relacją świadka i oskarżonego. Weryfikacja oraz uzupełnianie wyjaśnień i zeznań następuje poprzez odczytanie wcześniej złożonych relacji na podstawie regulacji art. $389 \S 1$ k.p.k. oraz odpowiednio $391 \S 1$ k.p.k. Należy zwrócić uwagę na to, że w tych przepisach przewidziany jest obowiązek odczytania protokołów wyjaśnień oskarżonego lub zeznań świadka jedynie „w odpowiednim zakresie", co wskazuje na niezbędny w danych okolicznościach zakres odstąpienia od bezpośredniości.

3) Względy związane z szybkością i sprawnością postępowania ${ }^{17}$. Przed nowelizacją Kodeksu postępowania karnego z 19 lipca 2019 roku $^{18}$ podstawę do takiego postępowania stanowił najczęściej przepis art. $392 \S 1$ k.p.k., zgodnie z którym wolno na rozprawie głównej odczytywać protokoły przesłuchania świadków i oskarżonych sporządzone w postępowaniu przygotowawczym lub przed sądem albo w innym postępowaniu przewidzianym przez ustawę, gdy bezpośrednie przeprowadzenie dowodu nie jest niezbędne, a żadna $\mathrm{z}$ obecnych stron temu się nie sprzeciwia. Jako przykłady takich przepisów można jeszcze wskazać art. 394 $\S 2$ k.p.k. pozwalający na uznanie protokołów i dokumentów za ujawnione bez odczytywania oraz art. $333 \S 2$ k.p.k. w zw. z art. $391 \S 1$ k.p.k. dający podstawę do zaniechania wzywania i odczytania na rozprawie zeznań świadków w sytuacji

16 Por. na przykład H. Paluszkiewicz, Zasada bezpośredniości, s. 1083 i literaturę tam wskazaną.

17 Por. na przykład S. Waltoś, op. cit., s. 272.

18 Dz.U. z 2019 r. poz. 1694. 
spełniania przesłanek tam opisanych. W literaturze słusznie wskazuje się, że niekiedy skorzystanie z dowodu pośredniego może paradoksalnie, poprzez usprawnienie postępowania, ułatwić dojście do prawdy ${ }^{19}$, upływ czasu może bowiem zniekształcić dowód pierwotny.

4) Potrzeba ochrony uzasadnionego interesu określonego uczestnika postępowania ${ }^{20}$. Zgodnie $\mathrm{z}$ ustawą $\mathrm{w}$ sprawach o przestępstwa popełnione $\mathrm{z}$ użyciem przemocy lub groźby bezprawnej lub określone w rozdziałach XXIII, XXV i XXVI kodeksu karnego pokrzywdzony, który w chwili przesłuchania nie ukończył piętnastu lat, przesłuchiwany jest w charakterze świadka tylko wówczas, gdy jego zeznania mogą mieć istotne znaczenie dla rozstrzygnięcia sprawy, i tylko raz, chyba że wyjdą na jaw ważkie okoliczności, których wyjaśnienie wymaga ponownego przesłuchania, lub żąda tego oskarżony, który nie miał obrońcy w czasie pierwszego przesłuchania pokrzywdzonego (art. 185a $\S 1$ k.p.k.). Przepis ten ma na względzie ochronę dobra dziecka pokrzywdzonego przez przestępstwo. Analogiczne odstąpienie od bezpośredniości może mieć miejsce w stosunku do świadka wskazanego w art. 185a $\S 2$ k.p.k. oraz pokrzywdzonego opisanego w art. 185c k.p.k. Warto wskazać, że w aktualnym stanie prawnym przesłuchanie w trybie art. 185a k.p.k., art. 185b k.p.k. oraz art. 185c k.p.k. poza obowiązkiem protokołowania tej czynności wiąże się z obowiązkiem utrwalenia przebiegu czynności za pomocą urządzenia rejestrującego obraz i dźwięk (art. 147 § 2a k.p.k.). Odtwarzanie takich zapisów na rozprawie zmniejsza skutki odstępstwa od bezpośredniości przesłuchania. Zapoznanie się z zapisami pozwala na obserwację osoby przesłuchiwanej, jej zachowania, reakcji na zadawane pytania, mimiki, gestykulacji, atmosfery panującej podczas przesłuchania oraz oceny innych elementów związanych z możliwością obserwacji czynności. Powoduje to, że cześć opisanych atrybutów związanych $\mathrm{z}$ realizacją bezpośredniości zostanie w tym przypadku dotrzymana mimo pośredniego przeprowadzenia dowodu. Odtwarzanie zapisów obrazu i dźwięku z przesłuchania pozwoli także na łagodzenie skutków ograniczenia prawa do obrony oskarżonego, które jest związane z brakiem możliwości osobistego uczestnictwa w przesłuchaniu.

5) W literaturze wskazuje się też, że część dowodów ze swej natury jest dowodami pośrednimi, co także wiąże się $\mathrm{z}$ ograniczeniem zasady bezpośredniości. Jako przykład wskazuje się opinię biegłego ${ }^{21}$, wywiad środowiskowy ${ }^{22}$ oraz protokoły oględzin ${ }^{23}$.

Najbardziej oczywistą i konieczną przyczyną rezygnacji z dyrektyw bezpośredniości jest konieczność ustalenia faktu za pomocą dowodu pochodnego, jeżeli dowód pierwotny nie jest dostępny lub nie istnieje. Wówczas korzystanie

19 H. Paluszkiewicz, Zasada bezpośredniości, s. 1087.

20 Por. A. Gaberle, op. cit., s. 175; H. Paluszkiewicz, Zasada bezpośredniości, s. 175 n.

21 J. Tylman, op. cit., s. 98.

${ }^{22}$ H. Paluszkiewicz, Zasada bezpośredniości, s. 1083.

23 S. Waltoś, op. cit., s. 271. 
z innych dowodów jest niezbędne i przy wykorzystaniu reguł z art. 7 k.p.k. daje sądowi dużo większe szanse na dokonanie prawdziwych ustaleń faktycznych niż w sytuacji, w której zrezygnowanoby z przeprowadzenia dowodów wtórnych. Podobnie niezbędne wydaje się odstępstwo od bezpośredniości związane z potrzebą sprawdzenia lub uzupełnienia dowodu (art. 389 § 1 k.p.k. i art. 391 § 1 k.p.k.). Zaznaczyć jednak należy, że to odstępstwo jest jedynie częściowe, gdyż sąd ma bezpośredni kontakt z osobą, której relacja jest odczytywana, dzięki temu może ocenić podawane przez nią informacje, w których świadek ustosunkowuje się do odczytanych protokołów, oraz jej zachowania, a także w razie potrzeby zadać pytania mające na celu ułatwienie oceny wiarygodności takiej osoby.

Potrzeba ochrony uzasadnionego interesu określonego uczestnika postępowania może wywoływać wątpliwości nie tylko w związku z koniecznością odstępstwa od bezpośredniości przeprowadzenia dowodu. Omówione wcześniej przypadki przewidujące takie sytuacje wiążą się z naruszeniem uprawnień związanych z prawem do obrony oraz zasadą równości broni. Podkreślić należy, że opisane w art. 185a k.p.k. odstępstwo od bezpośredniości przesłuchania świadka nie ma charakteru bezwzględnego. Ustawa przewiduje dwie podstawy nakazujące przesłuchanie takiej osoby po raz kolejny w postępowaniu sądowym. Do omawianej czynności dochodzi, gdy wyjdą na jaw istotne okoliczności, których wyjaśnienie wymaga ponownego przesłuchania, lub gdy żąda tego oskarżony, który nie miał obrońcy w czasie pierwszego przesłuchania pokrzywdzonego. Pierwsza opisana podstawa związana jest z potrzebą dokonania prawdziwych ustaleń faktycznych poprzez realizację bezpośredniości, druga zaś z zapewnieniem oskarżonemu należytego prawa do obrony. Ustawodawca osiągnął w ten sposób wyważony kompromis pomiędzy dobrem małoletniego pokrzywdzonego a realizacją zasad procesu karnego. W pierwszym przypadku zasady prawdy materialnej, zaś w drugim przypadku — zapewnieniem oskarżonemu należytych warunków do obrony, a także równości broni.

Dokonując analizy funkcjonowania zasady bezpośredniości w procesie karnym, należy w pierwszej kolejności przedstawić zmiany przepisów, które w ostatnich latach ograniczyły zakres jej obowiązywania. Poniżej zostaną przedstawione najważniejsze regulacje.

1) Wraz z wejściem w życie kodeksu postępowania karnego znacznie rozszerzono możliwość wydania wyroku bez konieczności przeprowadzenia rozprawy. Regulacje te stanowią największe odstępstwo od zasady bezpośredniości. Aktualnie przepisy pozwalają na orzekanie $\mathrm{w}$ taki sposób $\mathrm{w}$ przypadku rozpoznania wniosku o skazanie bez przeprowadzenia rozprawy (art. 335 § 1 i 2 k.p.k.), wydania wyroku warunkowo umarzającego postępowanie na posiedzeniu (art. 341 i 342 k.p.k.), skazania w wyniku rozpoznania wniosku skazanego o dobrowolne poddanie się odpowiedzialności (art. 387 i 338 a k.p.k.), wydania wyroku w wyniku ograniczenia postępowania dowodowego (art. 338 k.p.k.) oraz wydania wyroku nakazowego (art. 500-507 k.p.k.). Istnienie regulacji pozwalających na wyda- 
nie wyroku w tych trybach dotyczy wielu istotnych kwestii i wiele argumentów przemawia za takim rozwiązaniem. Ocena zakresu możliwości wyrokowania na posiedzeniu wykracza poza ramy niniejszego opracowania; dla osiągnięcia jego celów wystarczy wskazać wszystkie istotne przepisy wiążące się ograniczeniem bezpośredniości.

2) Kilkakrotnie nowelizowano treść przepisów art. 391 k.p.k. oraz art. 392 k.p.k., w tym częściowo rozszerzając odstępstwa od bezpośredniości przesłuchania świadka.

3) Wprowadzono przepis art. 177a k.p.k. umożliwiający przesłuchanie świadka za pomocą urządzeń technicznych przekazujących obraz i dźwięk ${ }^{24}$.

4) Wprowadzono regulacje 185a k.p.k., art. 185b k.p.k. i art. 185c k.p.k. przewidujące przypadki, w których — w zakresie tam opisanym i z uwagi na charakter przestępstw - pokrzywdzony co do zasady powinien być przesłuchany przez sąd tylko raz w postępowaniu przygotowawczym.

5) Wydłużono termin przerwy do 42 dni (art. $401 \S 2$ k.p.k.).

6) Stworzono możliwość przeprowadzenia przez sąd w szczególnie uzasadnionych wypadkach postępowania dowodowego podczas nieobecności oskarżonego lub obrońcy, który nie stawił się na rozprawę, będąc zawiadomiony o jej terminie, chociażby usprawiedliwił należycie niestawiennictwo (art. 378a § 1 k.p.k.).

7) Ograniczono przypadki nakładające obowiązek odczytania protokołów i dokumentów podlegających odczytaniu na rozprawie (art. 394 § 4 k.p.k.).

8) Wprowadzono regulację przyjmującą, że z chwilą zamknięcia przewodu sądowego ujawnione są bez odczytywania wszystkie protokoły i dokumenty podlegające odczytaniu na rozprawie, które nie zostały odczytane (art. $405 \S 2$ k.p.k.).

9) Rozszerzono przepisy określające zakres podmiotów, które mogą być przesłuchiwane za pomocą urządzeń technicznych przekazujących obraz i dźwięk (177 $\S 1$ b k.p.k., art.250 § 3b k.p.k., art. 374 § 3-9 k.p.k.).

Duża część zmian w przepisach ograniczających funkcjonowanie zasady bezpośredniości w polskim procesie karnym związana jest $\mathrm{z}$ nowelizacjami wprowadzonymi w życie w ciągu ostatnich kilkunastu miesięcy. Regulacje wskazane powyżej w punktach 5-8 wprowadzono nowelizacją dokonaną ustawą z dnia 19 lipca $2019 \mathrm{roku}^{25}$, natomiast opisane w pkt. 9 wprowadzono nowelizacją dokonaną ustawą z dnia 19 czerwca 2020 roku $^{26}$. Wprowadzenie ostatnich regulacji wypływa z konieczności zachowania bezpieczeństwa w związku zagrożeniem wirusem COVID-19. Wydają się one mieć charakter przejściowy, w związku z tym - mimo że mogą budzić wątpliwości odnośnie do tego, czy część wprowadzonych rozwiązań jest słuszna — z uwagi na ograniczenia dotyczące objętości niniejszego opracowania nie będą poddawane osobnej analizie.

24 Ustawa z dnia 31 sierpnia 2011 roku, Dz.U. z 2011 r. Nr 217, poz. 1280.
25 Dz.U. z 2019 r. poz. 1694.
26 Dz.U. z 2020 r. poz. 1086. 


\section{WĄTPLIWOŚCI, JAKIE MOGĄ SIĘ WIĄZAĆ Z ZAKRESEM REGULACJI MAJĄCEJ WPŁYW NA ZASADĘ BEZPOŚREDNIOŚCI.}

Dla oceny funkcjonowania zasady bezpośredniości niezbędna wydaje się analiza niektórych przepisów odnośnie do oceny słuszności przyjętych przez ustawodawcę uregulowań. W pierwszej kolejności należy krótko ocenić stosunek zasady bezpośredniości do innych zasad procesu karnego. Jak już wcześniej wskazano, spełnienie dyrektyw omawianej zasady służy realizacji zasady prawdy. Zasadniczo bezpośredniość znajduje potwierdzenie w regułach wynikających z ustności i kontradyktoryjności. Zasada ustności jest zasadą procesu karnego odnoszącą się przede wszystkim do postępowania dowodowego, a określającą formę czynności w sprawie. Brakuje ustawowej definicji ustności oraz pisemności w postępowaniu karnym. Najistotniejszy w tym zakresie jest przepis art. 365 k.p.k., zgodnie z którym rozprawa odbywa się ustnie, co odnosi się także do postępowania dowodowego, chyba że przepis szczególny reguluje tę kwestię odmiennie. Forma pisemna jest zastrzeżona dla niektórych czynności. Przestrzeganie ustności w procesie karnym w większości przypadków będzie tożsame $\mathrm{z}$ dochowaniem wymogów dotyczących bezpośredniości. Powiązania te są na tyle silne, że w literaturze przedwojennej obie zasady były utożsamiane ${ }^{27}$. W doktrynie wskazuje się, że zakresy pojęciowe obu zasad nie są tożsame, choć w przypadku dowodów osobowych zachowanie wymogów ustności będzie wiązało się z bezpośredniością zarówno wobec członków składu orzekającego, jak i stron. Natomiast w przypadku nieosobowych źródeł rzeczowych omawiana kwestia może wyglądać inaczej. Przykładowo przeprowadzenie dowodu z dokumentu może nastąpić przez jego ujawnienie bez odczytywania $^{28}$. Te słuszne uwagi należy ponadto uzupełnić o uwagi związane z dyrektywą dotyczącą zasady bezpośredniości. Mianowicie, mimo zachowania ustności w przypadku przeprowadzania dowodu o charakterze osobowym nie będzie zachowana bezpośredniość. Dotyczy to dowodów wtórnych, na przykład świadka ze słyszenia (,,z drugiej ręki”). W takiej sytuacji ustne przesłuchanie będzie miało charakter bezpośredniego kontaktu ze składem orzekającym i stronami, ale nie będzie spełniona dyrektywa nakazująca w miarę możliwości opieranie się na dowodach pierwotnych.

Najczęściej przyczyny odstępstw od bezpośredniości lub jej ograniczenia wiążą się z potrzebą zapewnienia szybkości i sprawności postępowania. Mamy wiele przypadków pozwalających na zakończenie procesu na podstawie materiału dowodowego zebranego w toku postępowania przygotowawczego, przy rezygnacji w całości lub w bardzo istotnej części z bezpośredniego postępowania dowodowego przed sądem. Najwięcej wątpliwości związanych z zasadnością ograniczenia

27 Por. H. Paluszkiewicz, Zasada bezpośredniości, s. 1120 oraz literaturę tam wskazaną.

28 Ibidem. 
bezpośredniości lub wprowadzania wyjątków dotyczy właśnie takich regulacji, które zmierzają do przyspieszenia i usprawnienia postępowania.

Jak już wcześniej podano, dla przedstawienia omawianych zagadnień istotna jest nowela Kodeksu postępowania z dnia 19 lipca 2019 roku, która wprowadziła kilka zmian przepisów wpływających na ograniczenie funkcjonowania zasady bezpośredniości w procesie karnym.

Pierwszym zagadnieniem wymagającym omówienia jest możliwość odstąpienia od przesłuchania pokrzywdzonego w charakterze świadka, jeżeli czynność ta nie jest niezbędna do dokonania ustaleń faktycznych (art. 315a k.p.k.). Wątpliwości w zakresie tej regulacji może budzić sytuacja, w której pokrzywdzony chce być przesłuchany. Ustawa nakazuje przesłuchać pokrzywdzonego w charakterze świadka, jeżeli jeszcze nie był przesłuchany w tym charakterze. Uprawnienie to nie ma jednak charakteru bezwzględnego, można od takiej czynności odstąpić w sytuacji, gdy uwzględnienie żądania prowadziłoby do przewlekłości postępowania. W przypadku braku kontroli tego typu decyzji mogłaby jednak wytworzyć się praktyka przyjmująca, że w większości sytuacji przesłuchanie pokrzywdzonego „prowadziłoby do przewlekłości postępowania”. Taki przepis może budzić wątpliwości co do respektowania regulacji art. 10 dyrektywy Parlamentu Europejskiego i Rady 2012/29/UE z 25 października 2012 roku ustanawiającej normy minimalne w zakresie praw, wsparcia i ochrony ofiar przestępstw oraz zastępującej decyzję ramową Rady 2001/220/WSiSW ${ }^{29}$. Zgodnie z tym przepisem należy zapewnić ofiarom przestępstwa możliwość bycia wysłuchanym podczas postępowania karnego i możliwość przedłożenia dowodów. Ustawa przewiduje obowiązek przesłuchania pokrzywdzonego w charakterze świadka, jeżeli ów tego zażąda, niemniej wyjątkiem jest sytuacja, gdy prowadziłoby to do przewlekłości postępowania. Ta ostatnia jest przesłanką o charakterze ocennym, zaś eliminacja jakichkolwiek trudności związanych z przesłuchaniem pokrzywdzonego zawsze będzie się wiązać $\mathrm{z}$ wydłużeniem toku procesu.

Dla realizacji zasady szybkości postępowania oraz zasady koncentracji istotne znaczenia ma także możliwość odroczenia i przerwy w rozprawie. Zagadnienia te również są powiązane z zasadą bezpośredniości. W sytuacji, gdy podjęcie decyzji o przerwie lub odroczeniu związane jest $\mathrm{z}$ chęcią przeprowadzenia dowodu pierwotnego, niewątpliwie wpływa to negatywnie na szybkość i koncentrację materiału dowodowego. Wówczas przeprowadzenie dowodu wtórnego będzie służyło realizacji tych zasad. Jak wskazuje się w literaturze, niekiedy takie rozwiązanie będzie też korzystne z uwagi na realizację zasady prawdy. Upływ czasu może bowiem zniekształcić dowód pierwotny, a w takiej sytuacji szybkie przeprowadzenie postępowania dowodowego zmniejsza ryzyko potencjalnego zniekształcenia ${ }^{30}$. Odnosząc się do obawy, jaka wiąże się ze zniekształceniem dowodów pierwotnych

29 Dz.U. L 315 z dnia 14 listopada 2012 roku, s. 57-73.

${ }^{30}$ H. Paluszkiewicz, Zasada bezpośredniości, s. 1087. 
w związku z długotrwałym postępowaniem, należy wskazać, że każde usprawnienie i przyspieszenie postępowania będzie ograniczało takie ryzyko. Warto też zwrócić uwagę na wprowadzoną omawianą nowelizacją zmianę ustawy wydłużającą maksymalny okres przerwy do 42 dni (art. $401 \S 1$ k.p.k.) $)^{31}$. Słuszność takiego rozwiązania może budzić wątpliwości. Obserwacja praktyki sądowej wskazuje na to, że sądy często korzystają z możliwości odroczenia rozprawy i prowadzenia jej na podstawie art. $401 \S 2$ k.p.k. w dalszym ciągu w tym samym składzie. Niejednokrotnie rozprawy sądowe są odraczane na kilkanaście tygodni. Wydłużenie maksymalnego okresu przerwy może być potraktowane przez składy orzekające jako akceptacja dla tego typu praktyk, co przy zachowaniu procentowych proporcji terminów odroczenia przy nowym maksymalnym okresie przerwy może skutkować wydłużeniem okresów odroczeń rozprawy. Konsekwencją powyższego może być między innymi większa liczba sytuacji, w których świadkowie będą słabiej pamiętać część okoliczności istotnych dla rozstrzygnięcia sprawy.

W wyniku opisanej wcześniej nowelizacji przepisów powstała też możliwość przeprowadzenia postępowania dowodowego w szczególnie uzasadnionych wypadkach przez sąd - podczas nieobecności oskarżonego lub obrońcy, który nie stawił się na rozprawę, będąc zawiadomiony o jej terminie, chociażby usprawiedliwił należycie niestawiennictwo - a zwłaszcza przesłuchania świadków, którzy stawili się na rozprawę, nawet jeżeli oskarżony nie złożył jeszcze wyjaśnień (art. 378a § 1 k.p.k.). Taka regulacja może budzić istotne wątpliwości co do realizacji wynikającego $z$ art. 42 ust. 2 Konstytucji RP oraz art. 6 ust. 3 lit. c EKPC prawa oskarżonego do udziału w postępowaniu dowodowym prowadzonym podczas rozprawy $^{32}$. Mając powyższe na uwadze, dokonując interpretacji tego przepisu należy odwołać się do wykładni prokonstytucyjnej i prokonwencyjnej. Za „szczególnie uzasadniony wypadek" wskazany w przepisie art. 378a § 1 k.p.k. można uznać sytuację, w której przeprowadzenie dowodu wiąże się z tym, że nie będzie ono możliwe na dalszym etapie postępowania. Wydaje się, że dla zachowania opisanych standardów przeprowadzenie dowodu powinno się wiązać z okolicznościami korzystnymi dla oskarżonego. Wątpliwości dotyczące prawa do obrony oskarżonego może też budzić ograniczenie prawa do złożenia wniosku o uzupełniające przeprowadzenie dowodu podczas nieobecności oskarżonego poprzez wskazanie terminu, po upływie którego uprawnienie takie nie będzie skuteczne. Jeżeli dojdzie do naruszenia prawa do obrony w wyniku przeprowadzania dowodu w warunkach opisanych $\mathrm{w}$ omawianym przepisie, to niedotrzymanie terminu złożenia wniosku o uzupełniające przeprowadzenie dowodu nie zmieni tej okoliczności.

Wątpliwości odnośnie do funkcjonujących rozwiązań w zakresie dotyczącym między innymi kwestii związanych z realizacją zasady bezpośredniości dotyczą

31 Projekt ustawy o zmianie ustawy - Kodeks postępowania karnego oraz niektórych innych ustaw z dnia 17 stycznia 2019 roku. Dostępny na stronie Rządowego Centrum Legislacyjnego, nr UD 465.

32 Szerzej zob. K. Nowicki, [w:] Proces karny, red. J. Skorupka, Warszawa 2020. s. 675-676. 
również art. $405 \S 2$ k.p.k. Przewiduje on, że z chwilą zamknięcia przewodu sądowego ujawnione zostają bez odczytywania wszystkie protokoły i dokumenty podlegające odczytaniu, które nie zostały wcześniej odczytane.

Jednocześnie w art. $405 \S 3$ k.p.k. wskazuje się, że takie ujawnienie będzie dotyczyć protokołów i dokumentów:

— wskazanych przez oskarżyciela w akcie oskarżenia jako dowody, których przeprowadzenia na rozprawie się on domaga, z wyjątkiem tych, co do których sąd oddalił wniosek dowodowy;

— wskazanych we wniosku dowodowym strony, który został uwzględniony;

— dopuszczone przez sąd z urzędu.

Brak chociażby sygnalizacji chęci ujawnienia takich dokumentów i protokołów może wiązać się z tym, że strona nie będąca podmiotem fachowym, w szczególności występująca bez udziału pełnomocnika lub obrońcy, może nie mieć jakiejkolwiek wiedzy o potrzebie zapoznania się z takimi dowodami oraz o możliwości ustosunkowania się do nich lub złożenia stosownych wniosków dowodowych. W praktyce sądowej często nie wydaje się postanowienia o dopuszczeniu dowodów zawnioskowanych przez oskarżyciela w akcie oskarżenia.

Ryzyko braku wiedzy przez stronę nie będącą podmiotem fachowym o potrzebie zapoznania się z takimi dowodami i możliwości ustosunkowania się do nich jest najbardziej realne w przypadku dopuszczenia dowodów przez sąd z urzędu na posiedzeniu niejawnym. Warto jednak zaznaczyć, że w uzasadnieniu wyroku sąd powoła się na dowody będące podstawą orzekania, zaś strona w środku odwoławczym będzie mogła ustosunkować się do tych dowodów. W sytuacji opisanej w przepisie art. $405 \S 3$ k.p.k. nie może też być w pełni realizowana jawność zewnętrzna. Publiczność obecna na sali rozpraw często może nie mieć choćby podstawowej wiedzy o dowodach, które będą podstawą wydanego orzeczenia kończącego postępowanie.

Zaznaczyć także należy, oceniając kolizję różnych dóbr, że nie wszystkie zmiany wprowadzone nowelizacją k.p.k. z dnia 19 lipca 2019 roku mogą wiązać się $z$ istotnymi wątpliwościami odnośnie do słuszności ich wprowadzenia. Przykładem regulacji, co do której podstawa odstąpienia od bezpośredniości uzasadnia konieczność takiego rozwiązania, jest art. 185c $\S$ la k.p.k. W sprawach o przestępstwa określone w $\S 1$ pokrzywdzonego, który w chwili przesłuchania ukończył piętnaście lat, przesłuchuje się w charakterze świadka tylko wówczas, gdy jego zeznania mogą mieć istotne znaczenie dla rozstrzygnięcia sprawy, i tylko raz, chyba że wyjdą na jaw istotne okoliczności, których wyjaśnienie wymaga ponownego przesłuchania.

\section{UWAGI KOŃCOWE}

Przedstawione rozważania pozwalają na przyjęcie, że dyrektywy zasady bezpośredniości mają istotny wpływ na kształtowanie się polskiego procesu kar- 
nego. W ostatnich latach wprowadzono szereg zmian przepisów, które wiązały się z ograniczeniem bezpośredniości lub wprowadzeniem od niej wyjątków. Jako najbardziej istotne w tym zakresie można wskazać instytucje skazania bez przeprowadzania rozprawy, dobrowolnego poddania się odpowiedzialności karnej, przesłuchania w toku postępowania przygotowawczego świadków w trybie art. 185a k.p.k., art. 185b k.p.k. i art. 185c k.p.k. Istotny w tym zakresie jest także przepis art. 392 § 1 k.p.k. pozwalający na odczytywanie na rozprawie głównej protokołów przesłuchania świadków i oskarżonych, sporządzonych w postępowaniu przygotowawczym lub przed sądem, albo w innym postępowaniu, gdy bezpośrednie przeprowadzenie dowodu nie jest niezbędne, a żadna ze stron się temu nie sprzeciwi, oraz przepis art. $394 \S 2$ k.p.k. umożliwiający uznanie protokołów i dokumentów za ujawnione bez odczytywania.

Trzeba też pamiętać, że w ostatnich latach nastąpiły istotne zmiany przepisów rozszerzające zakres bezpośredniości w procesie karnym. Zniesiono wcześniejsze ograniczenia dotyczące możliwości prowadzenia postępowania dowodowego przed sądem odwoławczym. Aktualnie sąd może przeprowadzić postępowanie dowodowe z zachowaniem bezpośredniości.

Istotna dla przyszłego kształtowania się bezpośredniości w toku procesu może być regulacja art. 177 § 1a k.p.k., która pozwala na przesłuchanie świadka przy użyciu urządzeń technicznych pozwalających na dokonanie tej czynności na odległość z jednoczesnym bezpośrednim przekazem obrazu i dźwięku. Korzystanie z nowoczesnych technologii może być czynnikiem wpływającym na coraz częstszą rezygnację z bezpośrednich przesłuchań. Zaznaczyć jednak należy, że tego typu przesłuchanie pozwala na obserwację świadka, jego mimiki, gestykulacji oraz na ocenę innych elementów związanych z możliwością obserwacji czynności. Można też zadawać pytania w reakcji na odpowiedzi świadka i jego zachowanie. Wykorzystanie art. 177 § 1a k.p.k. może wzmocnić dyrektywy bezpośredniości w wielu sytuacjach. Skład orzekający będzie miał bowiem znacznie większe możliwości oceny wiarygodności świadka przy takim przesłuchaniu niż przy przesłuchaniu świadka przez sąd wezwany (art. 396 § 2 k.p.k.). Innymi zagadnieniami wykraczającymi poza ramy niniejszego opracowania i nie związanymi z realizacją zasady bezpośredniości będą kwestie dotyczące zapewnienia swobody wypowiedzi świadka w przypadku przesłuchania przy użyciu urządzeń technicznych pozwalających na dokonanie tej czynności na odległość bądź zapewnienia odpowiednich warunków technicznych w tym zakresie.

Zasada bezpośredniości nie może mieć charakteru bezwzględnego i występować w czystej postaci. Takie rozwiązanie w wielu sytuacjach prowadziłoby do nadmiernego przedłużenia procesu z różnymi negatywnymi skutkami z tego wynikającymi, w tym dotyczącymi zniekształcenia dowodu na przykład w wyniku postępującej niepamięci świadków. W skrajnych przypadkach możliwe byłyby sytuacje, które zatrzymałyby bieg procesu. Należy pamiętać, że de lege lata większość przepisów kształtujących zasadę bezpośredniości określa nam wyjątki 
w tym zakresie. Podobnie de lege ferenda brak jest podstaw do stworzenia regulacji kształtujących zasadę bezpośredniości w czystej postaci. Niezależnie od powyższych uwag zachodzą sytuacje, w których nie będzie możliwa rezygnacja z dowodów pochodnych (na przykład jeżeli dowód pierwotny nie istnieje). Wówczas rezygnacja $z$ dowodów wtórnych znacznie ograniczyłaby możliwość dokonania prawdziwych ustaleń faktycznych. Dowody wtórne mogą mieć istotne znaczenie także w sytuacji, gdy korzystamy w tym zakresie z dowodu pierwotnego. Wiąże się to z możliwością oceny wiarygodności dowodu „z pierwszej ręki” zgodnie z dyrektywami określonymi w art. 7 k.p.k. Może to dotyczyć przykładowo zeznań świadków odnośnie do relacji świadka „pierwotnego” dotyczącej okoliczności, która jest przedmiotem dowodu tuż po tym, jak się wydarzyła.

Większość z opisanych ostatnich zmian przepisów może być uzasadniona w przekonujący sposób, jeśli będziemy je oceniać indywidualnie. Obawy budzi natomiast łączna ocena liczby i zakresu nowelizacji przepisów regulujących odstępstwa od zasady bezpośredniości.

\title{
DO THE ANTICIPATED CHANGES IN POLISH CRIMINAL PROCEEDINGS HAVE TO INVOLVE FAR-REACHING LIMITATION OF THE PRINCIPLE OF DIRECT EXAMINATION OF EVIDENCE?
}

\begin{abstract}
Summary
The principle of direct examination of evidence plays a crucial role in criminal proceedings. Rules derived from that principle affect the realization of the substantive truth principle because they indicate what types of evidence should be assessed by the court in order to determine which facts are true. This article discusses the scope and role of the principle of direct examination of evidence. Moreover, the changes in criminal procedure provisions regarding the functioning of this principle that occurred in recent years are analyzed and assessed. The study also presents possible threats to the proper functioning of Polish criminal proceedings associated with further extension of the direct examination of evidence principle.
\end{abstract}

Keywords: criminal procedure, the principle of direct examination of evidence, model of rational law-making, procedural guarantees

\section{BIBLIOGRAFIA}

Cieślak M., Zagadnienia dowodowe w procesie karnym, t. 1, Warszawa 1955.

Daszkiewicz W., Prawo karne procesowe, Zagadnienia ogólne, t. 1, Bydgoszcz 1999.

Gaberle A., Dowody w sadowym procesie karnym, Kraków 2007.

Grajewski J., [w:] Prawo karne procesowe - część ogólna, red. J. Grajewski, Warszawa 2011.

Glaser S., Wstęp do nauki procesu karnego, Warszawa 1928.

Glaser S., Zarys polskiego procesu karnego, Warszawa 1929.

Kmiecik R., [w:] Prawo dowodowe. Zarys wykładu, red. R. Kmiecik, Kraków 2005. 
Marszał K., Proces karny, Katowice 1997.

Murzynowski A., Istota i zasady procesu karnego, Warszawa 1994.

Nowak T., Zasada bezpośredniości w polskim procesie karnym, Poznań 1971.

Nowicki K., [w:] Proces karny, red. J. Skorupka, Warszawa 2020.

Paluszkiewicz H., Pierwszoinstancyjne wyrokowanie merytoryczne poza rozprawa w polskim procesie karnym, Warszawa 2008.

Paluszkiewicz H., Zasada bezpośredniości, [w:] System prawa karnego procesowego, red. P. Hofmański, t. 3. Zasady procesu karnego, cz. 2, red. P. Wiliński, Warszawa 2014.

Paluszkiewicz H., Zasada bezpośredniości a wyrokowanie poza rozprawa w przepisach kodeksu postępowania karnego, [w:] Nauka wobec współczesnych zagadnień prawa karnego w Polsce. Ksiega pamiatkowa ofiarowana profesorowi Aleksandrowi Tobisowi, red. B. Janiszewski, Poznań 2004.

Śliwiński S., Polski proces karny przed sądem powszechnym. Zasady ogólne, Warszawa 1948. Tylman J., Polskie postępowanie karne, red. T. Grzegorczyk, J. Tylman, Warszawa 2001.

Waltoś S., Proces karny. Zarys systemu, Warszawa 2009. 